\title{
JAPAN AND RUSSIA AT THE BEGINNING OF THE TWENTY-FIRST CENTURY: \\ - NEW DIMENSION TO MARITIME SECURITY SURROUNDING THE "KURIL ISLANDS"
}

\author{
Mihoko Kato ${ }^{1}$ \\ Hokkaido University
}

\begin{abstract}
:
Since Moscow decided to host the APEC Summit in Vladivostok, Russian policymakers and scholars have argued that Russia should be a "Euro-Pacific power". However, Russia's regional and bilateral priorities in Asia as well as her strategy to become a Pacific power remain uncertain. With the increase in the strategic significance of an ice-free Arctic, the sea of the Far Eastern region is gaining military importance for the Russian Navy. This article examines how the emergence of an ice-free Arctic could influence the security situation surrounding the "Kuril Islands".
\end{abstract}

Keywords: Japan, Russia, China, Territorial Disputes, the Arctic Sea Route, Maritime Security in the Asia-Pacific Region.

\section{Resumen:}

Desde que Moscú decidió albergar la cumbre APEC en Vladivostok, tanto decisores rusos como académicos han estado discutiendo sobre Rusia como una "potencia Euro-Pacífica". Sin embargo, las prioridades regionales y bilaterales de Rusia en Asia, así como su estrategia para convertirse en un poder Pacífico siguen siendo inciertas. Con el aumento en importancia de un Océano Ártico libre de hielo, el área marítima de la región del Lejano Este gana en importancia para la armada rusa. Este artículo examina cómo el deshielo en el Océano Ártico podría influir la seguridad en torno a las Islas Kuriles.

Palabras clave: Japón, Rusia, China, disputas territoriales, Ruta del Océano Ártico, seguridad marítima en la Región Asia-Pacífico.

Copyright $\odot$ UNISCI, 2013.

The views expressed in these articles are those of the authors, and do not necessarily reflect the views of UNISCI. Las opiniones expresadas en estos artículos son propias de sus autores, y no reflejan necesariamente la opinión de UNISCI.

\footnotetext{
${ }^{1}$ Dr. Mihoko Kato is a postdoctoral researcher at the Faculty of Letters at Hokkaido University, Japan. E-mail: m-kato@slav.hokudai.ac.jp.
} 


\section{Introduction}

This article discusses the influence of the growing importance of maritime security both in the Arctic Sea and the Sea of Okhotsk on the security situation in Northeast Asia, by focusing on the Japan-Russia relationship. Since Russia at the 2006 APEC Summit in Hanoi proposed hosting the 2012 APEC summit, the development of the Russian Far East has become a national priority and one of the main areas object of public investment. By the end of Putin's second presidency (May 2004-May 2008), the Russian government revised the federal target program "Economic and Social Development of the Russian Far East and Transbaikal from 1996 to $2010^{\prime 2}$ and extended the period of the program to 2013. Unlike Yeltsin's federal target program that did not work because of fund shortage, the revised federal target program secured financial resources by the federal budget both under the Putin and Medvedev presidencies. Although Russia's GDP growth rate fell sharply to $-7.8 \%$ in 2009 after recording a $7 \%$ average annual growth rate for the past eight years, the federal government did not reduce public investment in APEC preparation works.

As President Putin expressed in his speech at the APEC Economic Leaders' Meeting on 8 September 2012, Moscow's policy makers regard Vladivostok to be a Russian gateway to the Pacific Ocean and Southeast Asia as well as the shortest passage to Europe for AsiaPacific countries. In terms of Russia's integration policy towards the Pacific Rim countries, foreign observers tended to conclude that Moscow blames its dependence on China to gain a legitimate political and military presence in the Asia-Pacific region since the collapse of the Soviet Union and is striving to diversify its relations with other Asia-Pacific countries. ${ }^{3}$ There seems to be a consensus among experts on Russo-China relations that the close cooperative relationship between the two countries reached a peak around 2005 when Russian arms exports to China hit a new record of 3.1 billion US\$. ${ }^{4}$ Since then, the amount of arms trade has decreased and both countries have suffered from contradictions of national interests in military-technology cooperation, gas and oil prices, and relations with North Korea.

Sharing the view on Russia's diversification strategy, Natasha Kurt paid attention to the fact that in the Russo-Chinese border region of the Russian Far East, there are concerns that the federal government's development policy is based on the most optimistic scenario. ${ }^{5}$ Besides the federal target program for the period to 2013, the federal government adopted a "Long term development strategy for the Far East and Baikal for the period to 2025" in December 2009. In the "Strategy," the federal government set out to integrate the Russian Far East both with other Russian regions and neighboring Asia-Pacific countries by primarily securitizing Russia as an energy resource supplier. However, Kurt noted that although this official development "program" and "strategy" were elaborated as one of the means to lower the economic dependence on China, the Russian Far East will not be able to implement these

\footnotetext{
${ }^{2}$ This program was originally signed by the federal government in April 1996.

${ }^{3}$ Christophersen, Gaye: "Russia's Breakthrough into the Asia-Pacific: China's Role", International Relations of the Asia-Pacific, vol. 10, no. 1 (2010), pp. 61-62.

${ }^{4}$ The total amount of Russian arms export to China started to fall from 2006. In 2012, it was 0.68 billion US\$. See SIPRI, at http://armstrade.sipri.org/armstrade/page/values.php. As a cause of the reduction in arms trade between Russia and China, it is pointed out that Russia was displeased with China's practice of copying Russianmade weapons and selling them to third countries. See: The National Institute for Defense Studies Japan (2010): East Asian Strategic Review 2010, Tokyo, The Japan Times, Ltd., p. 189.

5 Kuhrt, Natasha: "The Russian Far East in Russia's Asia Policy: Dual Integration or Double Periphery?", Europe-Asia Studies, vol. 64, no. 3 (May 2012), p. 482.
} 
projects without China as a biggest energy importer as well as a major foreign investor into this region. ${ }^{6}$

On the one hand, Russia's Asia policy since 2006 has been examined primarily from the perspective of the necessity to reduce economic dependence on China in the Sino-Russian border region. On the other hand, the potential of diversification of the relations between Russia and Pacific Rim countries has not yet been sufficiently elucidated even after the Vladivostok APEC Summit. The following sections focus on Russia's growing interest in maritime security in Northeast Asia, particularly her relations with the major Pacific countries, China, and Japan. The second section explains the background regarding why Russia's strategic interests are growing not only in continental Asia but also in the Arctic and the Pacific Ocean under the third Putin administration (since 7 May 2012). The third section considers Japan's priority in Russia's Asia policy based on official documents. The fourth section argues about the changing importance of the Kuril Islands for Russia and the potential to expand Japan-Russia relations in the sphere of maritime security.

\section{Change in Regional Priorities in Putin's Foreign Policy}

The revised version of the Concept of the Foreign Policy of the Russian Federation was approved by President Putin on 12 February 2013 (hereafter "the Concept of 2013"). Originally, President Boris Yeltsin approved the Concept of the Foreign Policy of the Russian Federation in April 1993, and it was elaborated mainly by the Ministry of Foreign Affairs. Since then, the Concept was revised on the occasion of the change in administration both in 2000 and 2008. The Concept consists of five sections, which are "general provisions," "foreign policy of the Russian Federation and the modern world," "priorities of the Russian Federation for addressing global problems", "regional priorities" and "development and implementation of the foreign policy of the Russian federation", and shows the basic principles, priorities, and goals of Russia's foreign policy during the presidential term. Under the third Putin administration, the Concept of 2008 was revised taking into account the growing new trends in the international strategic circumstances during the Medvedev presidency.

In terms of Russian foreign policy makers' perception of current global politics, the Concept of 2013 says that "the ability of the West to dominate the world economy and politics continues to diminish. The global power and development potential now is now more dispersed and is shifting to the East, primarily to the Asia-Pacific region" and also that "the emergence of new global economic and political actors with Western countries trying to preserve their traditional positions is enhancing global competition, which is manifested in the growing instability in international relations." In these surroundings, Russia strives to provide support for emerging new powers through multilateral formats such as G20, BRICS, SCO, and RIC, while putting emphasis on her position as a permanent member of the Security Council of the United Nations. The substance of the new foreign policy concept is in principle based on the Concept of 2000, which was approved under the first Putin presidency.

\footnotetext{
${ }^{6}$ Kurt, op. cit., pp. 481-485.

7 "Contseptsiia vneshnei' politiki Rossii'skoi' Federatsii", signed by President V.V. Putin of the Russian Federation (12 February 2013), at

http://www.mid.ru/bdomp/ns-

osndoc.nsf/e2f289bea62097f9c325787a0034c255/c32577ca0017434944257b160051bf7f!OpenDocument.
} 
However, there are significant changes in the regional priorities and the order of bilateral relations concerning the Asia-Pacific policy in the Concept of 2013 as shown below.

Although the need for Russia's reorientation to a rising Asia-Pacific region has been actively discussed among Russian policy makers and academics for the past seven years, ${ }^{8}$ the position of the Asia-Pacific region was lowered on the list of regional priorities in the Concept of 2013. The previous two Concepts of 2000 and 2008 set the regional priorities as follows; post-Soviet space, Europe-Atlantic region, the United States, Asia-Pacific region, the Middle East, Africa, and Latin America. In addition to this, for the first time, the Concept of 2013 refers to the Arctic and puts the Arctic and the Arctic states in fourth place after the United States and before the Asia-Pacific region. Behind the growing emphasis on the Arctic, the number of days suitable for navigation through the Northern Sea Route is increasing with the changing climatic conditions in the north. As President Putin stated at a news conference on 20 December 2012, the federal government intends to revive the Northern Sea Route by establishing security points along its entire length. ${ }^{9} \mathrm{He}$ also mentioned the need to revive the airport at Tiksi, which is located on the Arctic sea coast of the Sakha Republic. ${ }^{10}$

The Northern Sea Route was initially formed to transport ordinary cargoes. However, it was used to supply Soviet frontier posts and military intelligence bases in the Arctic Ocean with equipment during the Cold War period. ${ }^{11}$ For ten years since the collapse of the Soviet Union, the Northern Sea Route lost its military role as well as cargo transport via the Arctic Ocean. However, since around 2000, the permanent ice cap that covered much of the Arctic Ocean has been melting caused by global warming year by year during summer. In this context, the Northern Sea Route, particularly the Northeast Passage which is a shipping route connecting the Atlantic Ocean with the Pacific Ocean along the northern coast of Russia, started to draw attention not only from Arctic states but also from non-Arctic actors. This route is more secure than existing sea routes connecting Europe with Asia primarily because the vessels navigating through the Northern Sea Route can avoid passing chokepoints such as the Strait of Malacca and the waters off the coast of Somalia.

In 2009, foreign merchant ships started to go through the Northeast Passage including three ships of the German company Beluga. ${ }^{12}$ The amount of cargo transported by this route increased from about 145,000 tons in 2010 to about 1.26 million tons in 2012. ${ }^{13}$ Also, the number of vessels has increased to thirty-four in 2012 from twenty-six in 2011. In particular, the shipping vessels bound for China and South Korea have been increasing more recently. There were eight vessels carrying energy resources to South Korea in 2012. Until 2011, most of the shipping vessels passing through the Northern Passage transported European products

\footnotetext{
${ }^{8}$ See: “Aziatsko-tikhookenaskii' sovet sotrudnichestva po bezopasnosti (АТССБ): Tikhookeanskaia strategiia Rossii (Russia's Pacific strategy)" (8 July 2012), at http://www.russkiymir.ru/export/sites/default/russkiymir/ru/events/advertisement/docs/Nikonov 080710.pdf; Karaganov, Sergei': “Aziatskaia strategiia: Rossiia v globalnoi” politike (Russia's Asian strategy: Russia in the global politics)" (17 June 2011), at http://www.globalaffairs.ru/pubcol/Aziatskaya-strategiya-15234.

9 "Press-Conference of Vladimir Putin" (20 December 2012), at http://kremlin.ru/transcripts/17173.

${ }^{10}$ However, the airport is currentry unacceptable according to the Defence Ministry's desision to close the airport. See: "Press-Conference of Vladimir Putin", op. cit.

11 "Russia Revives Northern", The Voice of Russia, 17 December 2012, at http://english.ruvr.ru/2012_12_17/Russia-revives-Northern-Sea-Route/.

${ }^{12}$ Ibid.

${ }^{13}$ This figure does not take account of domestic cargoes: Nihon Keizai Shimbun (NIKKEI), 5 January 2013, at http://www.nikkei.com/news/print-article/?R_FLG=0\&bf=0\&ng=DGXNASGM0405P_U3A100C1FF1000.
} 
to Asia-Pacific countries. However, in 2012 the first shipping vessel carrying fertilizer from China to Europe used the Northern Passage. ${ }^{14}$ Besides, at the end of 2012, Gazprom announced on its website that the company had successfully supplied LNG (liquefied natural gas) to Japan via the Northeast Passage for the first time in the world. ${ }^{15}$ It is still uncertain whether there is enough demand for LNG supply via the Northern Sea Route to Japan since Japan's import of Sakhalin-2 LNG has increased from 3\% (2009) to 9\% (2012). ${ }^{16}$ Furthermore, both governments agreed in principle to the joint construction of an LNG terminal in Vladivostok at the Japan-Russia Summit Meeting in September 2012. ${ }^{17}$ The Japan side was interested in expanding the import quantity of Russian LNG from Sakhalin and Vladivostok in order to reduce the import cost. Given this, it seems that the main purpose of Gazprom's announcement is to advertise the reasonability and the reality of the Northeast Passage to the world market. Thus, developing and securing the entire route of the Northeast Passage has become a high-priority task in order to show Russia's presence in the transportation system connecting Northeast Asian countries with European countries.

\section{Pragmatism in Russia's Foreign Policy towards Asia-Pacific Countries}

The other notable change in the Concept of 2013 is that the priority placed on relations with Japan became lower than described in the Concept of 2000. In terms of bilateral relations in the Asia-Pacific region, friendship relations with China and India are given top priority, followed by the Democratic People's Republic of Korea (hereafter DPRK) and the Republic of Korea, Japan, Mongolia, Vietnam, Australia, and New Zealand in the Concept of 2013. In the 2000 version, Japan was put in third place after China and India, and was followed by Iran and the Korean Peninsula. ${ }^{18}$ The first Japan-Russia Summit Meeting under the third Putin presidency was held at Los Cabos, Mexico to attend the G20 Summit. At the meeting, Putin agreed with the then prime minister Yoshihiko Noda to reactivate negotiations concerning the territorial issue that stagnated under the Medvedev administration. As for the economic sphere, Noda mentioned that he expected tangible progress such as the realization of the LNG project in Vladivostok and the participation of Japanese enterprises in the Sakhalin-3 project. $^{19}$ Unlike the former president Medvedev (May 2008-May 2012), Putin seems to have had an incentive to promote territorial negotiations with Japan. However, why has the priority of relations with Japan become lower than before?

Since the then president Medvedev visited the disputed island of Kunashir on 1 November 2010, the Medvedev administration has pursued an assertive policy towards the four disputed islands of Etorofu, Kunashir, Shikotan, and Habomai. On the one hand, Moscow embarked on the modernization of the military forces deployed on these islands. On

\footnotetext{
${ }^{14}$ Ibid.

${ }^{15}$ According to the Gazprom website, the Ob River LNG carrier chartered by the Gazprom group successfully supplies LNG from Norwegian Statoil's plant to the Tobata LNG terminal (Kita Kyushu, Japan): “Gazprom Successfully Completes World's First LNG supply via Northern Sea Route", Gazprom News, at http://www.gazprom.com/press/news/2012/december/article150603/.

${ }_{17}^{16}$ For the trade statistics of Japan, see: http://www.customs.go.jp/toukei/suii/html/data/y8 3.pdf.

17 See the official website of the Ministry of Foreign Affairs of Japan (MOFA): http://www.mofa.go.jp/policy/economy/apec/2012/j_russia_sm.html.

$\frac{18}{18}$ "Концепция внешней политики Российской Федерации", Утверждена Президентом Российской Федерации В.В.Путиным (28 Јune 2000) Под. ред. Торкунова, А. В.: Внешняя политика и безопасность современной России. 1991-2002. в 4-х томах, Т. 4., Документы. М., 2002., р. 119.

19 MOFA: "Japan-Russia Summit Meeting at the G20 Los Cabos Summit (Overview)", 19 June 2012, at http://www.mofa.go.jp/region/europe/russia/meeting1206_pm2.html.
} 
the other hand, the federal government accelerated the implementation of socio-economic development projects of the Kuril Islands in the framework of the federal target program "Social and Economic Development of the Kuril Islands (Sakhalin Oblast') in 2007-2015."20 When Foreign Minister Lavrov delivered a speech at a conference on socio-economic development of the Russian Far East and cooperation with the Asia-Pacific region in Khabarovsk on 2 July 2010, he mentioned the potential to expand economic cooperation, primarily with South Korea, and then with China and India, while ignoring relations with Japan $^{21}$. Some Japanese experts on Russia's foreign policy interpreted Lavrov's message as being that it was not worth expecting cooperation with Japan. ${ }^{22}$ According to the statistics published by the Far Eastern branch of the federal customs service, South Korea became the leading trade partner for the Far Eastern federal district in 2012. ${ }^{23}$ South Korea, Japan, and China accounted for $32.3 \%, 28.8 \%$, and $19.8 \%$ of the total exports of the Russian Far East respectively in 2012. As to the total imports, the percentages of these three countries were $46.3 \%$ for China, $17.9 \%$ for South Korea, and $9.4 \%$ for Japan. Furthermore, that "the potential for conflict in the Asia-Pacific remains significant, military arsenals are built up, and the risk of WMD proliferation is increasing" are referred to in the Concept of 2013. Moscow seems to recognize that the military threat has been growing in this region primarily because of North Korea's repeated missile launches and underground nuclear testing. Given these circumstances, the priority on bilateral relations in the Concept of 2013 is formed based on pragmatism in economic policy and military strategy.

\section{Emergence of a new Role of the "Kuril Islands" and Japan-Russia Relations}

Prior to publishing the foreign policy concept, President Putin instructed the federal government to develop the Navy, first and foremost in the Arctic areas and in Russia's Far East with the aim of protecting the Russian Federation's strategic interests by the "Executive order on implementing plans for building and developing the Armed Forces of the Russian Federation, other troops, military units, and agencies and modernizing the military-industrial complex," which was signed by President Putin on 7 May 2012. ${ }^{24}$ This section sets out to examine why Moscow intends to strengthen its naval forces in both areas.

First of all, an ice-free Arctic will allow military surface vessels to pass and submarines to surface in the Arctic Ocean. ${ }^{25}$ Following the demise of the Soviet Union, Russia's military

\footnotetext{
20 See: Federalnye Tselevye Programmy Rossii (FTsP): "Programma "Sotsialno-Ekonomicheskoe rasvitie Kuril'skikh Ostrovov (Sakhalinskaia Oblast') na 2007-2015 gody", at http://fcp.economy.gov.ru/cgi-bin/cis/fcp.cgi/Fcp/ViewFcp/View/2013/232/.

${ }^{21}$ See: Russian Presidency: "Steneograficheskii' otchet o soveshchanii po sotsialno-ekonomicheskomu razvitiiu dal'nego vostoka i sotrudnichestvu so stranami asistako-tikhookeanskogo regiona", at http://news.kremlin.ru/transcripts/8234/print.

${ }^{22}$ Opinion by Kazuhiko Togo, Asahi Shimbun, 11 November 2010.

23 See: Federal Customs Service (FTS), Far-East Customs Directorate: "Obzor bveshneekonomicheskoi' deiatel'nosti DV regiona za 2012 gd", at

http://dvtu.customs.ru/index.php?option=com content \&view=article \&id=11029:-2012-\&catid=63:stat-vneshtorg-cat\&Itemid=90.

${ }^{24}$ See: Russian President: "Podpisan ukaz o realizatsii planov pazvitiia Vooruzhennykh Sil i modernizatsii OPK" (7 May 2012), at http://kremlin.ru/acts/15242.

${ }^{25}$ See: "Maintaining the Order in the Arctic Ocean: Cooperation and Confrontation among Coastal Nations," in The National Institute for Defense Studies Japan, ed., East Asian Strategic Review 2011, Tokyo, The Japan Times, Ltd., 2011, p. 66.
} 
infrastructures were downsized in the Arctic region. If the Northern Passage is opened up to shipping in the near future, a number of foreign vessels would pass close to Russia's vulnerable northern coast. Russia's federal subjects on the northern coast face Canada and the United States across the Arctic Ocean. Therefore, while the revival of the Northeast Passage could promote the revitalization of the economy in the Russia's northern and Pacific coastal region, Russia's having to deal with a new strategic front would be inevitable. An ice-free Northeast Passage could also provide the Russian Navy with the shortest way to mobilize from the European theater to the East Asian theater, and vice versa. ${ }^{26}$ In this sense, the opening up the Northeast Passage to foreign vessels is still controversial from the military strategic standpoint.

In addition to the military and commercial use of an ice-free Northern Sea Route, natural resources such as oil and natural gas on the Arctic continental shelf are expected. China is not an Arctic littoral state: it has, however, conducted Arctic exploration by the research vessel 雪龍 (Xuelong) since 1994. ${ }^{27}$ There are two sea routes for Chinese naval vessels to leave the Pacific coast bound for the Arctic. One is the route sailing up the Pacific Ocean through the Tsugaru Strait. ${ }^{28}$ The other is the route passing the Okhotsk Sea and the Bering Sea through the Soya Strait. ${ }^{29}$ In October 2008, four Chinese vessels including a Sovremenny-class destroyer sailed through the Tsugaru Strait and circled around Japan. This navigation raised Russia's concern about China's future advance in the Arctic Ocean. ${ }^{30}$ It estimated that the shipping route from Shanghai to Hamburg via the Northeast Passage along the north coast of Russia was 6,400 km shorter than the passage through the Strait of Malacca and the Suez Canal. ${ }^{31}$ The Northern Sea Route would bring commercial benefits to China's economy that heavily depends on foreign trade.

China's icebreaker the Xuelong departed for its fifth Arctic exploration through the Northeast Passage via the Soya Strait in July 2012. After visiting Reykjavik (Iceland), the Xuelong changed its scheduled return route and tried the new route passing the North Pole for the reason that the Arctic sea ice was lower than expected. ${ }^{32}$ If vessels can develop the new shipping route passing the North Pole, they could avoid passing the exclusive economic zone (EEZ) of the Arctic littoral countries on most of the shipping route. ${ }^{33}$ This would lead to a saving of the transit rate to be paid to the Arctic littoral countries. The Xuelong successfully passed through the new Arctic Sea route in September 2012 for the first time except Russia. On the return route, the Xuelong did not pass the Okhotsk Sea although it was scheduled to do so, but sailed the Sea of Japan through the Tsugaru Strait. This route change is regarded to be

\footnotetext{
${ }^{26}$ Ibid., p. 78.

${ }^{27}$ The Xuelong is a 163-meter-long vessel with a displacement of 21,000 tons, the world largest non-nuclear icebreaker. It was purchased from Ukraine in 1993: Jakobson, Linda: "China Prepares for an Ice-free Arctic," SIPRI Insights on Peace and Security, no. 2010/2 (2010), p. 3.

${ }^{28}$ The Tsugaru Strait is the channel used for international navigation. This strait is located between the southern part of Hokkaido and the northern coast of Honshu (Japan's main island) connecting the Sea of Japan and the Pacific Ocean.

${ }^{29}$ The Soya Strait (La Pérouse Strait) is also used for international navigation. This channel is located between the southern coast of Sakhalin and the northern coast of Hokkaido connecting the Sea of Japan and the Okhotsk Sea.

${ }^{30}$ Hyodo, Shinji: "Chugoku ga mottomo onkei? Hokkyoku kouro no shutsugen = Ondanka de henka suru higashi ajia senryaku kankyou (Will China gain the maximum benefit? The emergence of the Northern Sea Route = Global warming causes the change in the security circumstances in East Asia)", Janet Jiji Press, 26 September 2012, at http://janet.jw.jiji.com/apps/do/auth/login.html.

${ }^{31}$ See: Jakobson, op. cit., p. 5.

${ }^{32}$ See: Sankei Shimbun, 7 September 2012.

${ }^{33}$ See: Sankei Shimbun, 7 September 2012.
} 
China's response to Russia's warning shot that was launched when the Xuelong was passing the southern part of Okhotsk onward. ${ }^{34}$

When China's vessels depart for the Arctic Ocean through the Soya Strait, they need to pass by the Kuril Islands, either the south coast of Paramushir or around Etorofu and Kunashir. The then president Medvedev planned to modernize the military bases on the Etorofu and Kunashir. ${ }^{35}$ As chief of the General Staff of the Russian Armed Forces, General Nikolai Makarov announced in August 2012 that Bastion or BAL mobile coastal defense missile systems could be deployed on the Kuril Islands. ${ }^{36}$ The modernization of the Russian military forces around the Kuril Islands can be seen to reinforce Russia's control against Japan's claim for sovereignty. However, considering that the missile range of the Bastion is $300 \mathrm{~km}$, it would be deployed to secure the shipping route around the Kuril Islands rather than to prevent the enemy landing on the islands ${ }^{37}$. In this context, with growing potential to utilize an ice-free Arctic Ocean, the Kuril Islands are playing a new role as a key strategic zone to control the passage of foreign vessels bound for the Arctic Ocean in addition to the traditional nuclear submarine base.

The negotiations on territorial issues over the four islands between Japan and Russia have been stagnant since the then president Medvedev visited Kunashir in November 2010, while Russian energy supply to Japan has been increasing since 2009. After taking power again, Putin has showed a willingness to reactivate the territorial negotiations with Japan. For instance, soon after the regime change to the LDP (Liberal Democratic Party, Japan) was ensured in December 2012, Putin stated that "we have received a signal from Tokyo, from the party that has come to power again, that the party's leadership will seek to conclude a peace treaty" and he added that "we highly value it and intend to conduct a constructive dialogue on the issue". ${ }^{38}$ On the one hand, he has repeatedly insisted that Japan and Russia should seek a mutually acceptable solution to the issue of territorial dispute. Taking into consideration the strategic significance of the Kuril Islands, especially Etorofu and Kunashir, it is not realistic to expect a major compromise from Russia over her principle position. On the other hand, Putin and the former prime minister Noda agreed to deepen their cooperation on the sea. It is notable that Noda said that Japan would like to promote concrete cooperation on the sea, including cooperation on the Arctic in the bilateral meeting with Putin. ${ }^{39}$ While the change in strategic circumstances surrounding the Kuril Islands could make territorial disputes more complicated, there would be opportunities to expand the cooperation on the sea close to the disputed islands.

\section{Conclusion}

In the annual presidential address to the Federal Assembly on 12 December 2012, Putin stated that Russia should ensure the unity of Russia's entire territory by developing the Northern Sea

\footnotetext{
${ }^{34}$ See: Hyodo, op. cit.

${ }^{35}$ See: The Siberian Times, 28 August 2012, at http://siberiantimes.com/other/others/news/russia-beefs-up-its-military-presence-on-kuril-islands/.

${ }^{36}$ See: "Russia to complete Kuril troops' reinforcement by 2014", Russia Today (RT), 28 August 2012, at http://rt.com/politics/kuril-islands-defense-military-736/.

${ }^{37}$ Koizumi, Yu: "Roshia no ajia taiheiyo senryaku (Russia's Asia-Pacific strategy)”, Kaigaijijo (October 2012), pp. 53-55.

38 "Press Conference of President Putin", op. cit.

39 See the official website of the Ministry of Foreign Affairs of Japan (MOFA): http://www.mofa.go.jp/policy/economy/apec/2012/j_russia_sm.html.
} 
Route, the Baikal-Amur Mainline (BAM), the Trans-Siberian Railway, and other transit corridors. ${ }^{40}$ As mentioned above, the regional priority of the Asia-Pacific region was put after the Arctic region in the Concept of 2013. These official documents show Russia's principle position that integrating Russia's frontier region into the domestic market inevitably comes before strengthening the relations between the frontier region and the neighboring Asian countries.

With the revival of the Northern Sea Route, attention started to be paid to the sea lanes connecting the Sea of Japan with the Okhotsk Sea as well as with the Pacific Ocean as the gateways to an ice-free Northern Sea Route. While an ice-free Arctic could bring Russia advantages as a new commercial route and access to undeveloped natural resources from the viewpoint of economic benefits, it would open a fourth strategic front followed by Europe, the Caucasus and Central Asia, and East Asia. In order to ensure her presence as an influential sea power in the Northeast Asia, Russia will strengthen the control and security in the Okhotsk Sea. Compared to the 1990s when the four disputed islands were ignored by the federal government, today these islands are likely to be granted the strategic responsibility for maritime security. On the other hand, Japan is facing the difficult problem of diversifying energy imports while reducing the dependence on nuclear power after the catastrophic earthquake on 11 March 2011.

The practical use of the Northern Sea Route should be examined carefully from various angles including the impact on the negotiations over the disputed islands between Japan and Russia. If an ice-free Arctic will be put to practical use for Northeast Asian countries, it could provoke the incentives for maritime security cooperation in the sea lanes from the Sea of Japan to the Bering Sea among the countries concerned. At the same time, the emergence of the Arctic Sea Route could be a factor that Russia needs the Kuril Islands (particularly Etorofu and Kunashir) more than ever for the security and control of the sea lanes. While respecting the historical process of negotiation over the territorial disputes, both states should establish a fruitful and pragmatic relationship responding to the change in the strategic circumstances surrounding the two countries.

\footnotetext{
${ }^{40}$ President of Russia: "Poslaniie Presidenta Federalnomu Sobraniiu" (12 December 2012), at http://kremlin.ru/transcripts/17118.
} 